IRA-International Journal of Management \& Social Sciences

ISSN 2455-2267; Vol.04, Issue 02 (2016)

Pg. no. 471-476

Institute of Research Advances

http://research-advances.org/index.php/RAJMSS

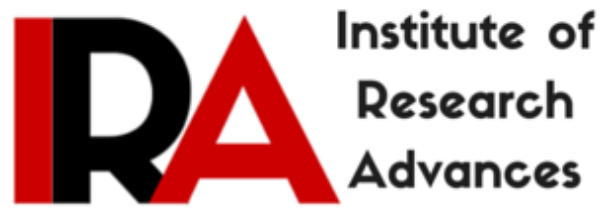

\title{
Role of Gender and Motivation across Banking Sector in India
}

\author{
${ }^{1}$ Beena Prakash \\ Research Scholar, \\ Pacific Academy of Higher Education and Research University, \\ Udaipur, India. \\ ${ }^{2}$ Dr. Anjali Panigrahi \\ Associate Professor, Chetana's H.S.College, India.
}

Type of Review: Peer Reviewed.

DOI: http://dx.doi.org/10.21013/jmss.v4.n2.p17

Prakash, B., \& Panigrahi, A. (2016). Role of Gender and Motivation across Banking Sector in India. IRA-International Journal of Management \& Social Sciences (ISSN 2455-2267), 4(2), 471-476. doi:http://dx.doi.org/10.21013/jmss.v4.n2.p17

(C) Institute of Research Advances

\section{(cc) EY-NC}

This work is licensed under a Creative Commons Attribution-Non Commercial 4.0 International License subject to proper citation to the publication source of the work.

Disclaimer: The scholarly papers as reviewed and published by the Institute of Research Advances (IRA) are the views and opinions of their respective authors and are not the views or opinions of the IRA. The IRA disclaims of any harm or loss caused due to the published content to any party. 


\begin{abstract}
Motivation is the basic drive for all of our actions. Motivation refers to the dynamics of our behavior, which involves our needs, desires, and ambitions in life. The role of gender in shaping motivation has a long history in psychological and educational research. This paper investigates the relationship between role of gender and motivational aspects of employees behaviour. The study comprised of analysing six motives (Achievement, Influence, Extension, Control, Affiliation and Dependency) by administering MAO-B questionnaire to respondents. Sample comprised of 102 respondents from Banking sector. The study shows that most significant motive influencing the managerial behaviour for both the gender is Extension followed by Achievement motive.
\end{abstract}

Keywords: Extension, Affiliation, Achievement, Managerial behaviour

\title{
Introduction:
}

Motivation refers to "the reasons underlying behaviour" (Guay et al., 2010). Motivation can also be defined as "the attribute that moves us to do or not to do something" (Gredler et al., 2004). A motivated employee is a loyal employee and to be loyal implies that the employee supports the actions and objectives of the firm. The appearance of the job as a whole has, in fact a bearing on the willingness and quality of an employee's performance (Bruce, 1962). A person's behaviour is the result of several factors or motives. Knowledge of the typical, primary motivators of behaviour in a work setting can help managers and consultants to deal more effectively with people. Murray (1938) developed a long list of human motives or needs and his work inspired further studies, which have produced different lists of significant behavioural motives. McClelland identified three important motives: achievement, affiliation and power (McClelland et al., 1953). Although McClelland's study of achievement and affiliation motives showed them to be rather simple variables, he found the power motive to be a complex one. The desire for power contains three different elements: the need to control others, the need to make an impact on others and the need to use power to do something for other people and groups (McClelland, 1975). Maslow (1943) advanced the following important prepositions about human behaviour: humans want beings (they always want and they want more), a satisfied need is not a motivator of behaviour and human needs are arranged in a series of levels-a hierarchy of importance. Maslow classified people needs in 5 categories: physiological, safety, social (sense of belonging), esteem and self-realization needs. Maslow said that, when an inferior rank need is satisfied (for example, assuring food, clothing, the need of breathing, etc), the next level need becomes dominant, and the attention of the person is dedicated to the accomplishment of this higher rank need. He mentioned that only an unsatisfied need can motivate the behaviour, the dominant need being the primary factor for behaviour motivation.

Managerial behaviour of an employee is defined as the in-role and extra-role behaviour of employee in an organisation. Motivation is important because it affects our lives everyday. Achievement motivation is based on reaching success and achieving all of our aspirations in life. Achievement goals can affect the way a person performs a task and represent a desire to show competence (Harackiewicz, Barron, Carter, Lehto, \& Elliot, 1997). These basic physiological motivational drives affect our natural behavior in different environments. Most of our goals are incentive-based and can vary from basic hunger to the need for love. Our motives for achievement can range from biological needs to satisfying creative desires or realizing success in competitive ventures. All of our behaviors, actions, thoughts, and beliefs are influenced by our inner drive to succeed. As motivation is the basic drive for all of our actions it is essential to analyse important motives that drives managerial behaviour.

\section{Literature Review:}

Murray (1938) developed a long list of human motives or needs. Murray's work inspired further studies, which have produced different lists of significant behavioral motives. McClelland, Atkinson, Clark, and Lowell (1953) suggested three important motives (achievement, affiliation, and power) and also suggested elaborate methods for measuring them. McClelland subsequently demonstrated the importance of the achievement motive for entrepreneurship and marketing (McClelland, 1961; 
McClelland \& Winter, 1971) and of power as a motivator in management (McClelland, 1975; McClelland \& Burnham, 1976).

Although McClelland's study of achievement and affiliation motives showed them to be rather simple variables, study found the motive of power to be a complex one. As he suggested during his study of power (McClelland, 1975), the desire for power contains both an urge to control others and an urge to make an impact. McClelland called these variables personalized power and socialized power. Thus, McClelland seems to suggest three different elements in the power motive: the need to control others (personalized power), the need to make an impact on others, and the need to use power in doing something for other persons and groups-such as in organizations (socialized power). It is helpful to make clear distinctions among these three. Control seems to be focused around keeping track of developments according to an agreed-on plan to be informed about "how things are going." This seems to be an important need or motive in managerial behaviour. The so-called socialized dimension of power (reflected in the use of power for the benefit of others) seems to be a separate need or motive. Pareek (1968a, 1968b) suggests that this need is important for social development and calls it the extension motive. The need for achievement was defined by McClelland (1985) as a concern with "doing things better,with surpassing standards of excellence". Decades of research have shown n Achievement to be related to moderate risk taking, responsiveness to feedback, future-timeorientation, personal responsibility for performance outcomes, and participation in entrepreneurial activity. It is not surprising that research on gender and achievement motivation has been influenced by prevailing views about gender differences. Stewart and Chester (1982) focused their review of these differences on two areas-differential responses to achievement arousal and behavioural correlates of achievement.

Many researchers believed that it was difficult to arouse achievement motivation in women, most likely because achievement was seen as an exclusively masculine concern. It was also quite likely that because the original arousal studies had only male participants, key imagery to distinguish between high and low achievement-motivated women was left out of the coding categories. Stewart and Chester (1982) reviewed the early research on the arousal of $n$ Achievement, and, after pointing out flaws in research design and missed opportunities to interpret main effects, they concluded that there is no consistent evidence that the motive was difficult or impossible to arouse in women.

\section{Objectives:}

In today's challenging work environment, engaging and motivating the tweeting generation is emerging as the biggest challenge. It is widely recognized in the human resource literature that promotion of the motivation of workers in both private and public organisations leads to a higher quality of human resources and optimum performance. Consensus is also growing among managers about the significance of combining good human resource performance approaches on motivation incentives to encourage good performance. Hence, it becomes important for the management to understand what drives the managerial behaviour.

\section{Hypothesis:}

Although Miner's research (1993) demonstrates no difference in managerial motivation between women and men in managerial positions in recent years in the USA, the question remains if these findings are generalizable to other countries. Based on the results of recent studies of managerial motivation of females and males in the USA (Miner, 1993; Miner and Smith, 1982; Miner et al., 1985), Hong Kong (Ebrahimi, 1997a), and the PRC (Chen et al., 1997) we postulate the following:

$\mathrm{H}_{1}$ : Managerial motivation for males and females employees are different . 


\section{Research Methodology:}

\section{Tool Used:}

\section{MAO-B INSTRUMENT}

The Motivational Analysis of Organizations-Behavior (MAO-B) instrument contains sixty items, five for each dimension (approach and avoidance) of the six motives is used to study motivational aspects of managerial behaviour. The test-retest reliability coefficients for the six dimensions are between .61 .

\section{Sample and Sampling technique:}

To study motivational aspects of managerial behaviour MAO-B was administered to 102 BPO professional (46\% Male and 54\% Female) . In the absence of any Sampling Frame and due to paucity of time, the sampling technique used was convenience.

\section{Data Analysis and Result:}

Table 1 shows mean and Standard deviation of both male and female gender for all the six motives (Achievement, Influence, Extension, Control, Affiliation and Dependence). The above table shows mean value of achievement motive for male (2.6) is higher than female (2.5). As standard deviation for female is higher than males shows females have comparatively less homogeneity in perception towards motivation. For Extension motive and dependency motive mean value is higher than male counterparts.

\section{Table 1 Descriptive Statistics}

\begin{tabular}{|ll|l|l|l|l|l|l|}
\hline Gender & & Ach_Mot & Influence & Exten & Control & Affiliation & Dependency \\
\hline MALE & Mean & 2.60 & 2.66 & 2.46 & 2.46 & 2.46 & 1.80 \\
& $\mathrm{~N}$ & 45 & 45 & 45 & 45 & 45 & 45 \\
& Std. Deviation & .80 & .79 & .81 & 1.03 & .72 & .54 \\
FEMALE & Mean & 2.52 & 2.26 & 3.84 & 1.68 & 2.05 & 2.63 \\
& $\mathrm{~N}$ & 57 & 57 & 57 & 57 & 57 & 57 \\
& Std. Deviation & 1.40 & 1.02 & 6.75 & 1.03 & .69 & 1.14 \\
Total & Mean & 2.55 & 2.44 & 3.23 & 2.02 & 2.23 & 2.26 \\
& $\mathrm{~N}$ & 102 & 102 & 102 & 102 & 102 & 102 \\
& Std. Deviation & 1.17 & .949 & 5.10 & 1.10 & .733 & 1.01 \\
\hline
\end{tabular}

Table 2 shows significant difference in the mean value of male and female gender for all the six motives (Achievement, Influence, Extension, Control, Affiliation and Dependency.

\section{ANOVA Table}

The table show relationship is significant for influence motive $(\mathrm{p}=.032)$, control $(\mathrm{p}=.000)$, affiliation $(\mathrm{p}=.004)$ and dependency $(\mathrm{p}=.000)$ motive.

\section{Table 2 : Anova Table}

\begin{tabular}{|c|c|c|c|c|c|c|c|}
\hline & & & $\begin{array}{ll}\text { Sum } & \text { of } \\
\text { Squares }\end{array}$ & df & Mean Square & $\mathrm{F}$ & Sig. \\
\hline Ach_Mot $*$ Gender & $\begin{array}{l}\text { Between Groups } \\
\text { Within Groups } \\
\text { Total }\end{array}$ & (Combined) & $\begin{array}{l}137 \\
139.011 \\
139.147\end{array}$ & $\begin{array}{l}1 \\
100 \\
101\end{array}$ & $\begin{array}{l}.137 \\
1.390\end{array}$ & .098 & .755 \\
\hline Influence $*$ Gender & $\begin{array}{l}\text { Between Groups } \\
\text { Within Groups } \\
\text { Total }\end{array}$ & (Combined) & $\begin{array}{l}4.094 \\
87.053 \\
91.147\end{array}$ & $\begin{array}{l}1 \\
100 \\
101\end{array}$ & $\begin{array}{l}4.094 \\
.871\end{array}$ & 4.703 & .032 \\
\hline Extension * Gender & $\begin{array}{l}\text { Between Groups } \\
\text { Within Groups } \\
\text { Total }\end{array}$ & (Combined) & $\begin{array}{l}47.574 \\
2580.779 \\
2628.353\end{array}$ & $\begin{array}{l}1 \\
100 \\
101\end{array}$ & $\begin{array}{l}47.574 \\
25.808\end{array}$ & 1.843 & .178 \\
\hline Control $*$ Gender & $\begin{array}{l}\text { Between Groups } \\
\text { Within Groups }\end{array}$ & (Combined) & $\begin{array}{l}15.396 \\
107.516\end{array}$ & $\begin{array}{l}1 \\
100\end{array}$ & $\begin{array}{l}15.396 \\
1.075\end{array}$ & 14.320 & .000 \\
\hline
\end{tabular}




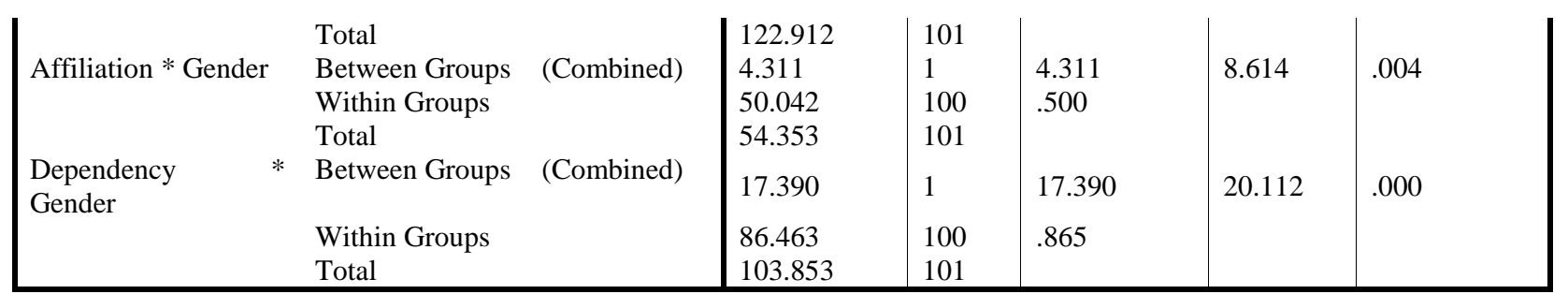

Table 3 below shows $p>\alpha$ for affiliation and control motive. Hence Equal variance for the control and affiliation motive is verified.

Table 3 Independent Samples Test

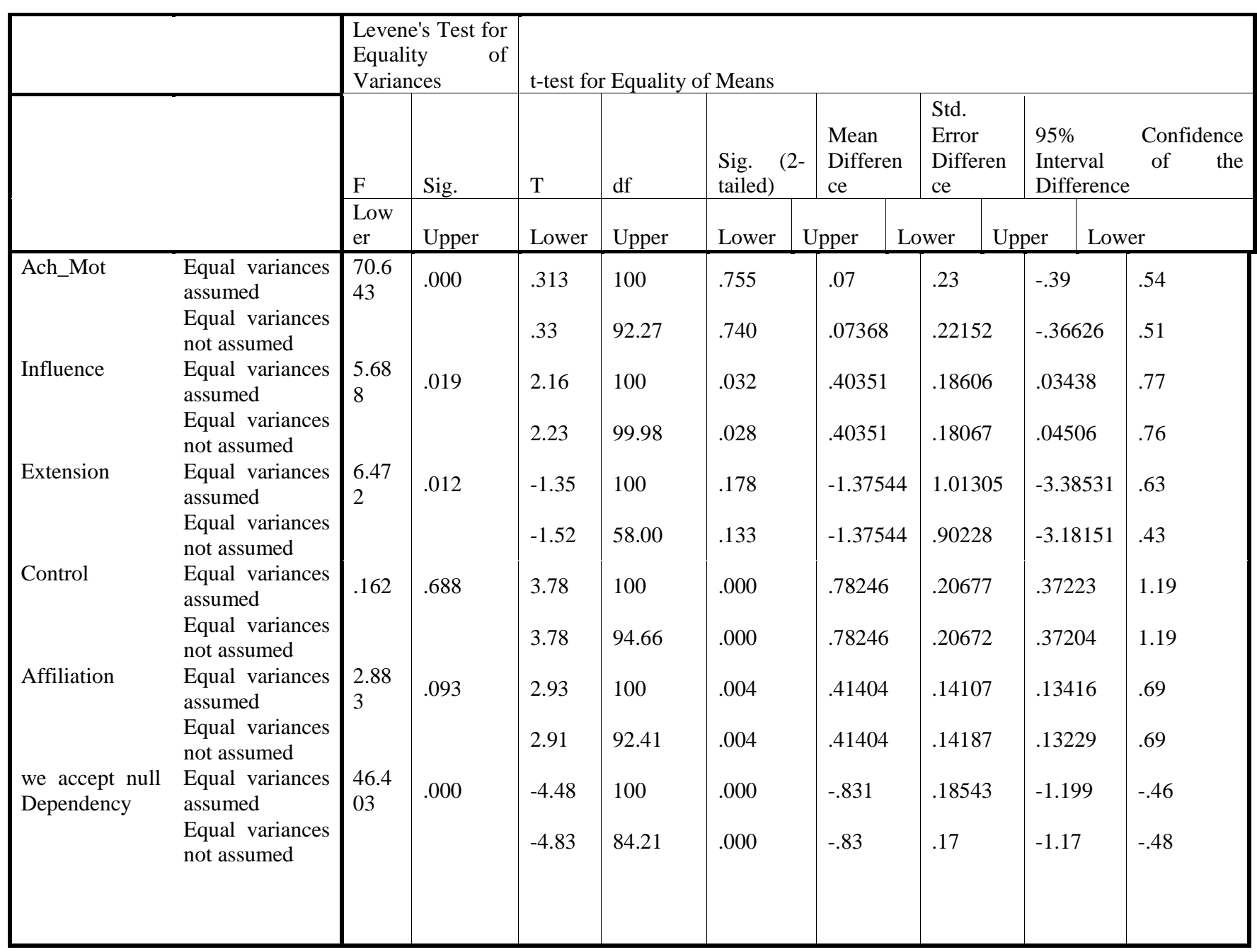

As equality of variance is shown by only control and affiliation motive. Hypothesis are tested only for control and affiliation motive. Table 4 below shows $\mathrm{p}$ value for control motive (.000) is lower than $\alpha$ and also for affiliation motive $\mathrm{p}$ value $=.004$ is lower. Null hypothesis is rejected that is there is no difference in the mean of control and Affiliation motive for male and female gender. From Table 1 it can be inferred mean value of control motive(2.4) for male is higher than female (1.6) and also for affiliation motive mean value for male (2.4) compared to female (2.0) is higher. 


\section{Conclusion:}

Study shows affiliation motive and control motive are influencing employees of Banking sector. Thus, no difference in the motives influencing both the genders in the Banking. From descriptive statistics it could be inferred mean value of control motive and affiliation motive for male is higher than female. Miner's research (1993) demonstrates no difference in managerial motivation between women and men in managerial positions in recent years in the USA. This study supports findings of Miners study which shows no difference in motivational aspects for both the gender at the workplace.

\section{References}

- Chan, D. \& Kumaraswamy, M. (1997) A comparative study of causes of time overruns in Hong Kong construction projects. International Journal of Project Management, 15, 1.

- Construction Industry Board (1996) Tomorrow's Team: Women and Men in Construction. Thomas Telford, UK.

- Cope, B. \& Kalantzis, M. (1997) Productive Diversity. Pluto Press, Australia. Court,

- G. \& Moralee, J. (1995) Balancing the Building Team: Gender Issues in the Building Profession. Institute for Employment Studies, Brighton, England.

- Dainty, A., Bagilhole, B. \& Neale, R. (2000a) A grounded theory of women's under achievement in large UK construction companies. Construction Management and Economics $18,239 \pm 250$.

- Maloney, W.F. \& McFillen, J.M. (1986a) Motivation in unionized construction. Journal of Construction Engineering and Management, 112, 1.

- Maloney, W.F. \& McFillen, J.M. (1986b) Motivational implication in construction work. Journal of Construction Engineering and Management, 112, 1.

- Maslow, A.H. (1943) A theory of human motivation. Psychological Review, 50.

- Maslow, A.H. (1992) A theory of human motivation. In: Management and Motivation (eds V. Vroom \& E.12 Deci), pp. 39 \pm 52 . Penguin, England. McClelland, D.C. (1975). Power: The inner experience. New York: Irvington.

- McClelland, D.C., Atkinson, J.W., \& Lowell, E.L. (1953). The achievement motive. New York: Irvington.

- McGregor, D. (1966). Leadership and motivation. Cambridge, MA: MIT Press.

- Murray, H.A. (1938). Explorations in personality. New York: Oxford University Press.

- Pareek, U. (1986). Motivational analysis of organizations-behavior (MAO-B). In J.W. Pfeiffer and L.D. Goodstein (Eds.), The 1986 annual: Developing human resources. San Diego, CA: Pfeiffer \& Company. 